\title{
Kedudukan lafaz قطع اليد dalam kajian usul dan pengaruhnya terhadap hukuman potong tangan
}

\author{
Salma \\ Fakultas Syariah IAIN Imam Bonjol Padang \\ E-mail:salma_nathiqa@yahoo.com
}

Understanding about punishment of stolen which is commonly heard and understood by the society is amputation of the hand. The punishment is explained clearly in the holy Quran. However, there are different interpretations about the punishment. This paper is elaborated from library research by collecting, deviding and reading many sources which appropriate with the topic and then analize the data in descriptive way. The interpretations are based on different view in usul fiqh. These differences arise from the words qat' and $y a d$ which have more than one meaning. The meaning of the qat' are not only as an amputation but also as hurt and anticipation. Beside that, the yad means knukles, fingers to wrist even to soldier. As a result, these differences also influence the limitation of the hand which is amputated (qat" al-yad) in the Quran.

Pemahaman hukuman pencurian yang telah biasa didengar dan dipahami masyarakat ialah potong tangan seperti yang dijelaskan dalam al-Qur'an. Sekalipun demikian masih terdapat perbedaan pendapat tentang hukuman potong tangan yang sebenarnya dari sudut pandang usul fikih. Tulisan ini diolah dari studi kepustakaan dengan mengumpulkan, memilah, membaca buku-buku yang membahas tentang topik ini, kemudian dianalisis secara deskriptif. Kajian ini mendapati bahwa perdebatan dilatarbelakangi oleh lafaz qat' dan yad yang mempunyai makna lebih dari satu. Makna qat' menurut bahasa tidak hanya memotong tetapi juga bermakna memecah/melukai dan mencegah. Selain itu makna yad mulai dari ruas-ruas jari, ujung jari sampai pergelangan, sampai siku atau sampai pangkal lengan. Perbedaan ini juga dengan sendirinya memberi pengaruh pada batas pemotongan tangan (qat' al-yad) yang dimaksud dalam al-Qur'an.

Keywords: Steal; Ușül fiqh; Punishment; Hand amputation 
ljtihad, Jurnal Wacana Hukum Islam dan Kemanusiaan, Volume 13, No. 1, Juni 2013: 85-104

\section{Pendahuluan}

Pencurian ialah salah satu dari jenis ḥudüd yang telah dijelaskan hukumannya oleh Allah swt. dalam al-Qur'an. Sekalipun demikian, masih terdapat berbagai perbedaan pendapat yang mengitari pelaksanaan hukuman potong tangan seperti yang dijelaskan dalam ayat. Pada pencurian ini perbedaan pendapat banyak terjadi pada makna tangan dan batas tangan yang akan dipotong, nisab harta curian dan dalil-dalil yang mendukungnya. Terjadinya perbedaan pendapat pada pelaksanaan hukuman juga menimbulkan perbedaan pendapat di kalangan ulama. Perdebatan ini antara lain terjadi pada pengertian dan batas tangan ( اليد ) sebagai objek yang akan dipotong. Terdapat riwayat yang berbeda-beda di kalangan sahabat Nabi saw. tentang batas potong tangan ini. Perbedaan pendapat juga terjadi pada pengertian lafaz sebagai ḥudūd yang bisa diganti dengan hukuman lainnya. Para ahli ilmu di antaranya beralasan bahwa perkataan القطع mempunyai makna lain yang melahirkan kemungkinan untuk mengalihkan pengertiannya kepada selain makna hakiki yaitu terputus dan terpisah dari bagian tubuh.

\section{Lafaz قطع اليد dalam kajian usul fikih}

Hadd potong tangan dalam jināyah pencurian disyariatkan oleh Allah swt. dalam surat alMà'idah ayat 38 sebagai berikut:

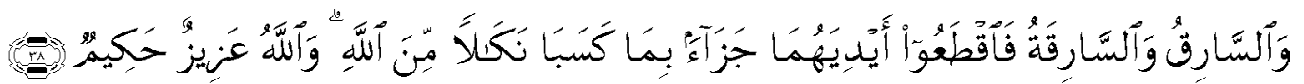

"Laki-laki yang mencuri dan perempuan yang mencuri, potonglah tangan keduanya (sebagai) pembalasan bagi apa yang mereka kerjaka dan sebagai siksaan dari Allah. Dan Allah Maha Perkasa lagi Maha Bijaksana.”

Pada ayat ini Allah swt. memerintahkan untuk melaksanakan hukuman potong tangan pada orang yang melakukan pencurian. Perintah tersebut menggunakan lafaz فاقطعو آليديرما. Ada dua pendapat berbeda tentang kedudukan lafaz فاقطعو آليديهنا dalam surat al-Mácidah ayat 38 ini. Ada ahli usul yang mengatakan lafaz ini termasuk pada kategori lafaz الئحمالئل dan ada pula ahli usul lain yang mengatakan lafaz فاقطعو آيلديهن tidak termasuk pada kategori lafaz البحمل , tetapi masuk pada kategori lafaz mutlaq. Untuk lebih jelas dapat dilihat dalam uraian berikut ini. 


\section{Lafaz قطع اليد اليد}

Para ahli usul berbeda pendapat tentang firman Allah dalam surat al-Mā'idah ayat 38 ini. Sebagian ahli usul dari ulama mazhab Hanafi mengatakan bahwa lafaz اليد القطع lafaz lan ialah lafaz بحمل (Subkiy, t.th: 58). Sifat mujmal pada lafaz القطع bisa bermakna terpisah atau terangnya (إلبانة) antara satu anggota tubuh dengan anggota tubuh lainnya. Makna lain ialah pecah atau terkelupas kulit (الشتق) anggota tubuh karena luka dengan tidak terpisah dari anggota tubuh. Hal ini dapat dikatakan seperti seseorang telah melukai tangan orang lain seperti seseorang meruncing pensil. Perbuatan itu diungkapkan dengan kata قطع يده. Adapun sifat ïmal pada lafaz اليد ialah pada makna tangan secara keseluruhannya. Pengertian tangan dikatakan sampai ke bahu atau pangkal lengan (المنكب), sampai ke mata siku (المرفق), ataupun sampai ke pergelangan tangan (الكوع). Seluruh makna tangan ini sama benarnya dalam pemahaman orang Arab. Oleh karena itu lafaz القطع dan bersifat mujmal (al-Amidiy, t.th: 17-18).

Dalam ungkapan lain dinyatakan bahwa lafaz فاقطعبر آثيديهما ialah mujmal, karena pengertian tangan bisa jadi sampai ke bahu apabila hal itu yang dimaksud dengan keseluruhan tangan. Ada juga kemungkinan bisa memotongnya sampai ke pergelangan tangan (الكو ع) karena hal itulah yang menjadi batas ukuran pemotongan tangan dalam jināyah pencurian ini. Ada juga kemungkinan untuk memotongnya sampai ke mata siku (المرفق) karena sampai batas ini masih disebut tangan dalam berwudhuk. Pendapat ini juga didukung oleh dalil lain dengan mengatakan ungkapan harian yang biasa dituturkan orang Arab bahwa seseorang telah memotong tangan orang lain. Maksud dari ungkapan itu ialah bahwa ia telah memotong tangan orang lain dan membuat tangan orang itu terpisah dari bagian tubuhnya. Ungkapan itu dapat juga bermakna ia hanya menarik tangannya dan ia tidak membuat tangan itu terpisah dari tubuhnya. Biasanya ungkapan terluka atau terpisahnya anggota tubuh harus menggunakan lafaz القطع. Oleh sebab itu, bisa dikatakan bahwa tangan seseorang telah dipotong seluruhnya seperti telah dipotong dahan/cabang dari pohonnya (al-Mu'taziliy, 1964: 336-337).

Secara lebih rinci, makna اليد yang sebenarnya dapat dilihat melalui berbagai pendapat berikut ini: 
a. حتيقة اليد من المنكب

Menurut pengertian bahasa makna اليد dimulai dari ujung jari-jemari sampai ke bahu (alMu'taziliy, 1964: 336-337). Oleh karena itu, harus dipahami makna tangan menurut bahasa kecuali ada dalil lain yang memalingkan pengertian itu, maka dalil itu dapat diterima.

Berdasarkan pemahaman ini maka lafaz ayat فاقطعو آيديهما bersifat mujmal, karena makna yang dikehendaki pada ayat itu bukan makna zahirnya.

Sesungguhnya pengertian اليد tidak meliputi pergelangan tangan saja. Tidak ditemukan dalam ungkapan bahasa dipotong tangan seseorang, baik sebagian ataupun seluruh tangan, jika bagian yang dipotong hanya telapak tangan (الكفف) saja. Walaupun makna الكف itu meliputi ukuran tangan, baik sebagian tangan maupun seluruh tangan.

b. حقيقة اليد من المرفق

Pengertian اليد dimulai dari ujung jari sampai ke mata siku berdasarkan ayat al-Qur'an yang menjelaskan tentang perintah berwudhu dalam surat al-Mà-'idah ayat 6 sebagai berikut:

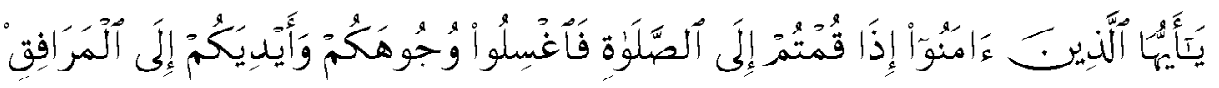

"Hai orang-orang yang beriman, apabila kamu hendak mengerjakan shalat, maka basuhlah mukamu, dan tanganmu sampai dengan siku."

Pada ayat ini Allah swt. menjelaskan bahwa tangan yang mesti dibasuh dalam berwudhuk ialah sampai ke mata siku. Atas dasar ini, ada ulama mazhab Syiah yang berpendapat bahwa batas potong tangan dalam kasus pencurian ialah sampai ke mata siku (إلى المرفقن) ini (al-'Amiliy, 1991: 490). Namun pendapat ini dibantah oleh mayoritas ulama Syiah lainnya yang mengatakan bahwa batas potong tangan dalam pencurian ialah jari-jemari saja dan telapak tangan (sampai ke batas bahu masih menyatu dengan tubuh)

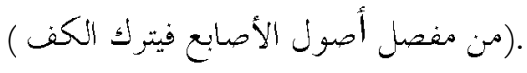

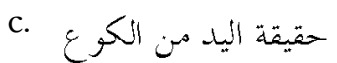

Pengertian tangan dimulai dari ujung jari sampai pada pergelangan tangan. Pendapat ini dikemukakan oleh jumhur fuqaha yang dinukilkan secara ijmak. Pendapat ini berdasarkan pada ayat al-Qur'an surat al-Mā'idah ayat 6 sebagai berikut: 


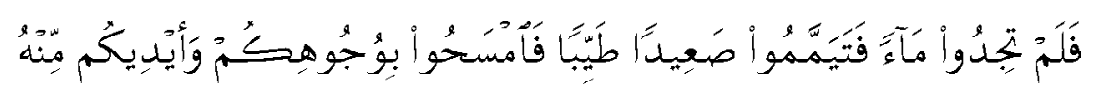

“...lalu kamu tidak memperoleh air, maka bertayammumlah dengan tanah yang baik (bersih), sapulah mukamu dan tanganmu dengan tanah itu.”

Ayat ini menjelaskan anggota badan yang mesti disapu ketika bertayammum yaitu muka dan kedua tangan. Selain berdalil pada ayat di atas, mereka juga berdalil pada hadis yang menjelaskan masalah yang sama yaitu:

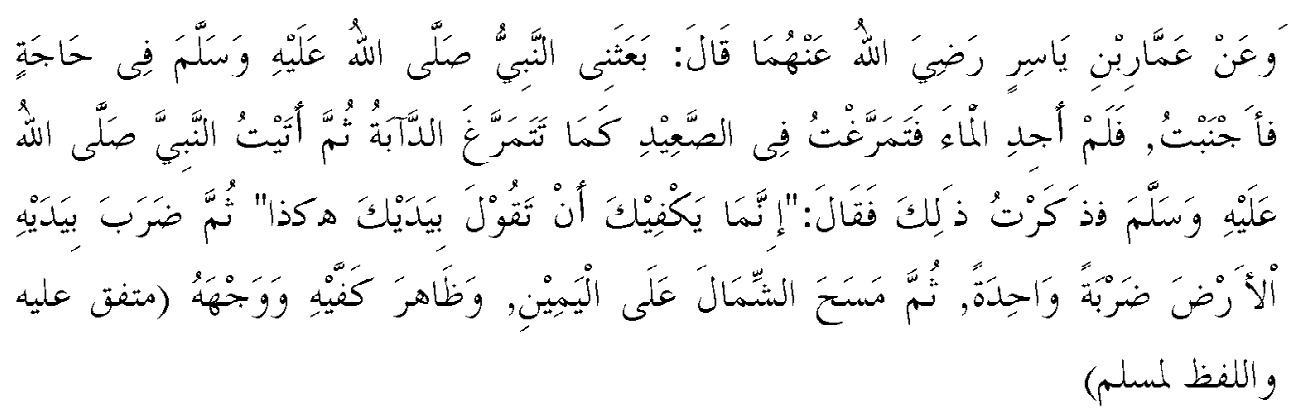

“Hadis diriwayatkan dari'Ammar ibn Yasir r.a. ia berkata: Rasulullah saw. telah mengutusku pada satu keperluan, kemudian aku berhadas besar (berjunub), dan aku tidak mendapatkan air, maka aku bergulingan di tanah seperti bergulingnya hewan melata. Setelah itu aku berjumpa Rasulullah saw. dan menceritakan hal itu itu kepadanya. Lalu Rasulullah saw. bersabda:"Cukuplah engkau melakukan dengan tanganmu seperti ini." Kemudian Rasulullah saw. memukul tanah dengan kedua tangannya satu kali pukulan, kemudian menyapukan tangan (bagian) kirinya ke (bahagian) tangan kanan dan sebaliknya, kemudian menyapu kedua telapak tangan dan wajahnya” (al-San'aniy, 1997: 139-140).

Dalam hadis ini Rasulullah saw. membetulkan ijtihad 'Ammar ibn Yasir yang menggunakan tanah sebagai pengganti air. Rasulullah saw. menunjukkan kepadanya cara bertayammum yang benar dan menunjukkan pergelangan tangan sebagai batas sapuan tanah pada tangan. Dengan demikian hadis ini menjadi salah satu di antara dalil yang mendukung pendapat mayoritas ahli fiqh bahwa batas potong tangan ialah pergelangan tangan.

Selain berdalil pada surat al-Ma'-idah ayat 6 dan hadis 'Ammar ibn Yasir ini, mayoritas ulama juga berdalil pada hadis Rasulullah saw. sebagai berikut:

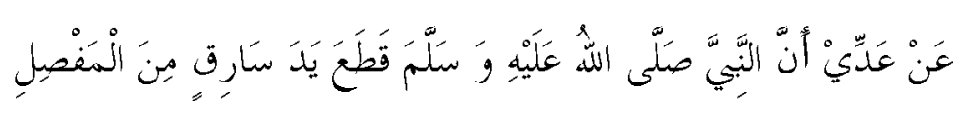


ljtihad, Jurnal Wacana Hukum Islam dan Kemanusiaan, Volume 13, No. 1, Juni 2013: 85-104

"Hadis diterima dari 'Addiy bahwa Nabi saw. telah memotong tangan seorang pencuri dari pergelangan tangannya" (al-Baihaqqiy, 1994: 470).

Hadis ini menjelaskan bahwa batas potong tangan dalam pencurian ialah pergelangan tangan. Berdasarkan dalil-dalil yang telah disebutkan di atas, maka tidak terdapat sifat بكمل pada lafaz ayat فاقطع آيديهن. Oleh sebab itu, Rasulullah saw. telah memotong

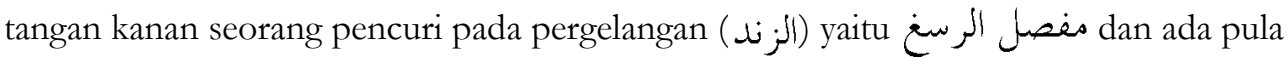
yang menyebut pergelangan tangan ini dengan kata النكو ع لنو (Nujaim, 2002: 99).

d. حقيقة اليد من أصول الأِصابع

Pengertian اليد ialah jari-jemari saja. Pendapat ini dinukilkan dari Ali ibn Abi Talib. Pada dasarnnya ada berbagai periwayatan yang diterima dari Ali yang melaksanakan hukuman potong tangan pada pencuri. Satu riwayat mengatakan bahwa Ali memotong tangan pencuri yaitu jari-jemarinya dan memotong ujung satu ruas jari budak yang mencuri. Ali juga memotong setengah bagian telapak kaki pencuri dan pergelangan kaki masih menyatu dengan tubuh (Qal'ajiy, 1996: 332-333). Pendapat Ali ini diikuti oleh ulama mazhab Syiah. Dalam sebuah kasus pencurian pada masa pemerintahan al-Mu'tasim dari Dinasti Bani Abbas diceritakan bahwa seorang pencuri telah mengaku melakukan pencurian. Hakim bertanya kepada si pencuri sebelum menyucikan dirinya dengan hukuman hadd. Maka berkumpullah para ulama mazhab Syiah dalam musyawarah berkenaan. Salah seorang di antara mereka ialah ahli fikih terkemuka Syiah yaitu Muhammad ibn Ali. Ia bertanya kepada orang-orang yang hadir tentang batas potong tangan. Ibn Abi Daud mengatakan bahwa batas potong tangan pada pencurian ialah pergelangan tangan berdasarkan ayat al-Qur'an dan hadis yang menjelaskan batas tangan dalam bertayammum. Para ahli fikih yang hadir ketika itu setuju dengan pendapatnya.

Abu Ja'far mengatakan bahwa batas potong tangan ialah mata siku ( من المرفق ) berdasarkan ayat al-Qur'an dan hadis yang menjelaskan batas tangan dalam bertayammum juga. Muhammad ibn Ali membantah pendapat yang dikemukakan oleh Abu Ja'far dan mengatakan bahwa pendapat itu menyalahi Sunnah Rasulullah saw. Batas potong tangan dalam pencurian ialah jari-jemari dan telapak tangan sampai ke bahu masih menyatu dengan tubuh (من منصل أصول الأصابع فيترك الكف) si pelaku (al-'Amiliy, 1991: 490). Pendapat ini berdasarkan hadis Rasulullah saw. sebagai berikut: 


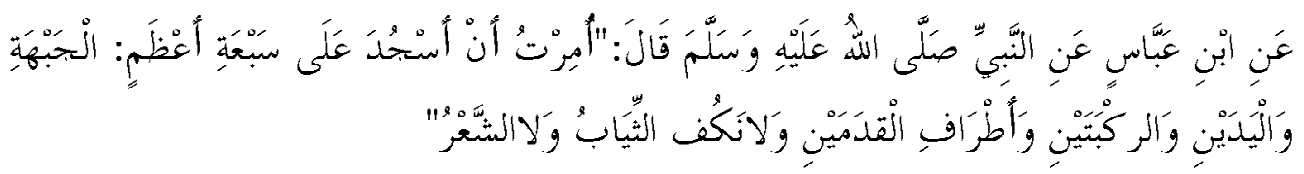

"Hadis diriwayatkan dari Ibn 'Abbas dari Nabi SAW beliau bersabda:"Aku diperintahkan untuk bersujud di atas tujuh anggota utama badan yaitu dahi, dua tangan, dua lutut, dua kaki dan dua ujung jari-jari kaki, dan tidak apa-apa untuk melipat lengan baju dan tidak apa-apa pula apabila rambut menutupi dahi” (al-Samarqandiy, 2000: 316).

Hadis ini menjelaskan bahwa terdapat tujuh anggota badan yang bersujud kepada Allah swt. dalam shalat yaitu dahi, dua tangan, dua lutut, dan dua ujung kaki. Apabila dipotong tangan pencuri, baik pada pergelangan tangan maupun pada mata siku, maka tidak ada lagi bagian telapak tangannya (seperti yang dimaksudkan dalam hadis) untuk bersujud kepada Allah swt. Selain itu, Allah swt menyatakan dalam surat al-Jinn ayat 18 sebagai berikut:

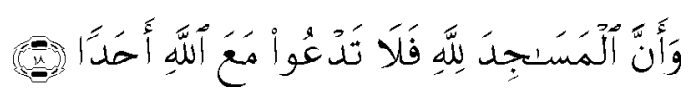

Artinya: Dan sesungguhnya mesjid-mesjid itu adalah kepunyaan Allah. Maka janganlah kamu menyembah seorangpun di dalamnya di samping (menyembah) Allah.

Ayat ini dijadikan dasar bahwa anggota tubuh yang tujuh bersujud kepada Allah dan tidak menyeru Allah dengan sesuatu yang lain. Oleh karena itu, Allah swt. tidak akan menyuruh umat-Nya untuk memotong anggota-anggota badan yang menyeru kepada-Nya.

Pada riwayat kedua disebutkan bahwa Ali memotong tangan pencuri sampai ke pergelangan tangan (النكو ع) dan memotong kaki pencuri sampai ke pergelangan kaki (الكعبين) nya (Qal'ajiy, 1996: 333). Pada riwayat ini dinyatakan bahwa Ali memotong tangan dan kaki pencuri kemudian mengobatinya sampai sembuh (Hazm, t.th: 354-355), berdasarkan pada perintah Rasulullah saw. seperti dijelaskan dalam hadis berikut ini:

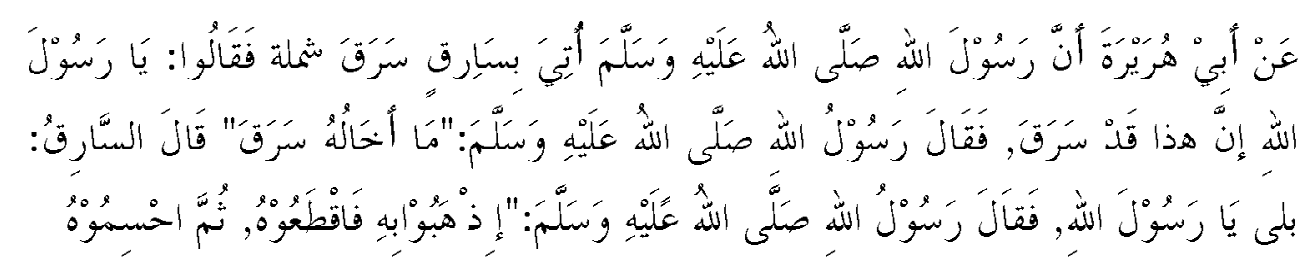


ljtihad, Jurnal Wacana Hukum Islam dan Kemanusiaan, Volume 13, No. 1, Juni 2013: 85-104

"Hadis diriwayatkan dari Abi Hurairah bahwa Rasulullah saw didatangkan kepadanya seorang pencuri yang telah mencuri sebuah baju jubah. Orang-orang yang membawa (si pencuri) berkata kepada Rasulullah saw: Wahai Rasulullah sesungguhnya orang ini telah mencuri, Rasulullah saw berkata:"Aku tidak menyangka ia seorang pencuri!' Si pencuri menjawab: Benar aku telah mencuri wahai Rasulullah, maka Rasulullah saw bersabda:'Kamu semua pergilah dengan si pencuri ini, kemudian potonglah tangannya, setelah itu obatilah!" (al-Baihaqqiy, 1994: 471).

Pada hadis ini Rasulullah memerintahkan untuk mengobati tangan si pencuri yang telah

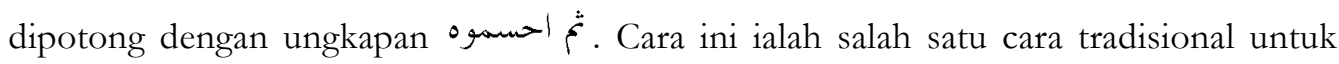
menghentikan pendarahan dengan menggunakan api. Sekiranya pendarahan tidak dihentikan, maka akan memberikan mudarat lain kepada si pencuri, bahkan pendarahan terus-menerus akan mematikannya. Sedangkan tujuan hukuman ḥadd pada kasus ini salah satunya ialah untuk mendidik serta menjerakan dan tidak untuk mematikan si pelaku.

Pada riwayat yang ketiga Ibn Hazm mengatakan bahwa Ali memotong tangan pencuri sampai ke pergelangan tangannya dan memotong satu ujung ruas jari budak yang mencuri (Hazm, t.th: 355).

\section{Lafaz. فق tidak bersifat mujmal}

Mayoritas ahli usul lainnya mempunyai pendapat yang berbeda dengan pendapat di atas mengenai firman Allah والسارق والسارقة dalam surat al-Māiidah ayat 38. Mereka mengatakan

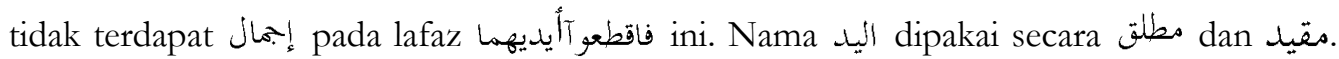

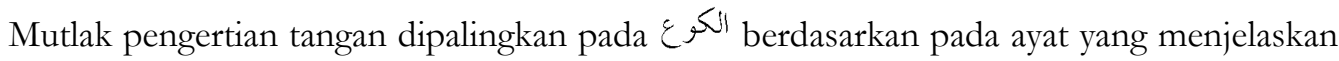
cara bertayammum, ayat pencurian, dan ayat ḥirābah. Secara hakiki ( حقيقة ) makna tangan ialah sampai ke bahu, sedangkan pengertian tangan sampai ke mata siku dan pergelangan tangan ialah majāz. (ب). Dengan demikian tidak ada ijmal pada ayat ini. Sunnah Rasulullah SAW telah menjelaskan bahwa potong tangan dalam kasus pencurian ialah sampai ke الكو ع.

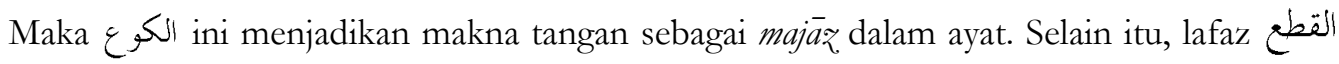

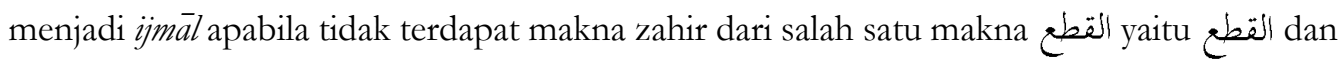

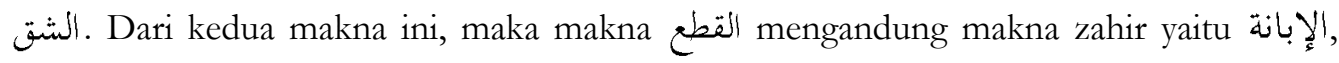
sedangkan الثتت tidak mengandung makna zahir yaitu terpotong/terluka, tetapi tidak terpisah dari anggota badan (al-Syaukaniy, t.th: 24). 
Ibn Subkiy mengatakan bahwa lafaz ayat فاقطعو آ أيديهما sebagai ḥadd al-sâriqah ini tidak bersifat mujmal, baik pada lafaz اليد اليد maupun pada lafaz (Subkiy, t.th: 58). Sekalipun ulama mazhab Hanafi mengemukakan berbagai kemungkinan pengertian kedua lafaz tersebut, tetapi Ibn Subkiy mengatakan bahwa perkataan tangan meliputi anggota tubuh sampai ke bahu. Adapun pengertian pemotongan ialah nyata terpisahnya salah satu anggota tubuh dari badan secara keseluruhan. Lugasnya penjelasan syarak mengenai pergelangan tangan ( ل sebagai batas pemotongan menjadi penjelas (مبين) bahwa yang dimaksud dengan (keseluruhan) tangan pada lafaz ayat فاقطع آأيديهما ialah sebahagian dari tangan yang dipotong.

Pengertian lafaz فاقطعو آأيديهما sebagai lafaz yang tidak bersifat أبحمل juga dikaitkan dengan firman Allah swt. dalam al-Qur'an surat al-Màidah ayat 6 dan surat al-Mámidah ayat 38 sebagai berikut:

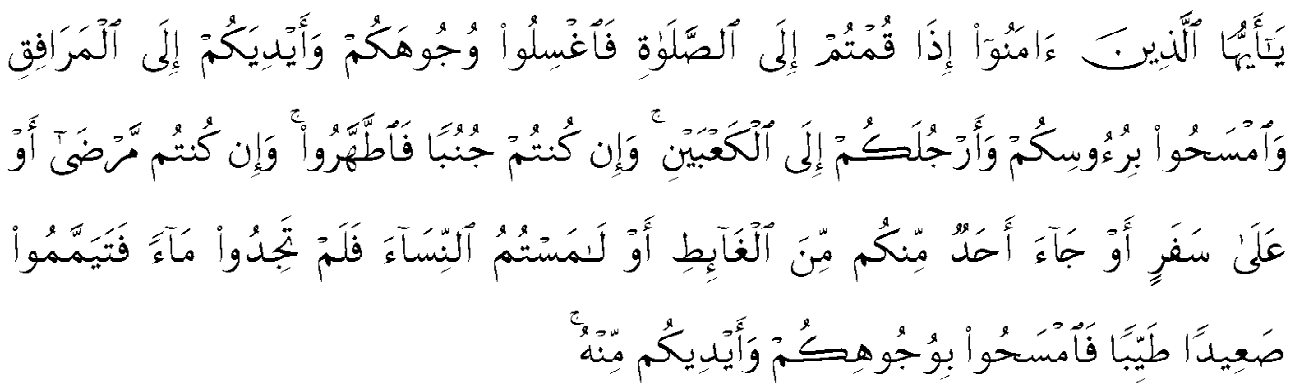

'Hai orang-orang yang beriman, apabila kamu hendak mengerjakan shalat, maka basuhlah mukamu dan tanganmu sampai dengan siku, dan sapulah kepalamu, (basuh) kakimu sampai kedua mata kaki, dan jika kamu junub, maka mandilah, dan jika kamu sakit, atau dalam perjalanan, atau kembali dari tempat buang air (kakus), atau menyentuh perempuan, lalu kamu tidak memperoleh air, maka bertayamumlah dengan tanah yang baik (bersih), sapulah mukamu dan tanganmu dengan tanah itu."

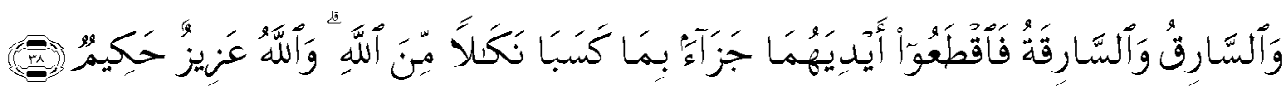

"Laki-laki yang mencuri dan perempuan yang mencuri, potonglah tangan keduanya (sebagai) pem balasan bagi apa yang mereka kerjakan dan sebagai siksaan dari Allah. Dan Allah Maha Perkasa lagi Maha Bijaksana." 
ljtihad, Jurnal Wacana Hukum Islam dan Kemanusiaan, Volume 13, No. 1, Juni 2013: 85-104

Pada ayat 38 surat al-Màidah ini dijumpai lafaz فاقطعو آليديهما dan pada ayat 6 surat yang sama dijumpai lafaz وأيديكم :إلى المرافق. Pada kedua ayat ini terdapat perbedaan antara hukum

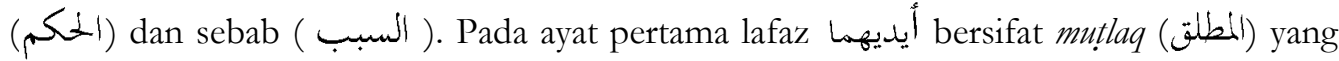
tidak dikaitkan dengan sesuatupun. Pada ayat kedua bersifat muqayyad (المقيد) yaitu dikaitkan dengan lafaz إلى المرافت. Hukum pada kedua ayat ini berbeda yaitu perintah untuk potong tangan pada ayat pertama (فاقطعو آليديهما). Perintah untuk membasuh tangan pada ayat kedua. Begitu juga terdapat perbedaan

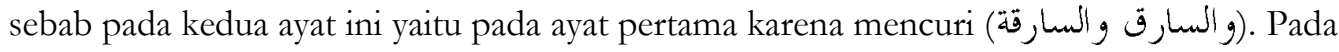
ayat kedua ialah kehendak untuk mendirikan shalat (إذاقتمتم :إلى الصبلوة).

Pada kedua contoh ayat ini para ahli usul fiqh sependapat bahwa tidak dipakaikan ayat yang bersifat mut\}laq pada ayat yang bersifat muqayyad, tetapi tetap ayat mutlaq atas kemut \}laq-annya dan tetap pula ayat muqayyad pada taqjid-nya seperti dalam ungkapan berikut ini لابيحمل المطلق على المتقيد بل يبقى المطنق على إطلا قه و المُقيد على تقييد (Salih, 1993: 213-214). AlAmidiy mengatakan bahwa tiada perbedaan pendapat untuk menghalang pemakaian حمل المطلق على المتقيد (al-Amidiy, t.th: 17-18).

Alasan yang dikemukakan pada ijtihad ini ialah kedua ayat yang mutlaq dan muqayyad ini tidak saling menafikan, sedangkan kaidah الحمل hanya saja diperlukan untuk menghilangkan sifat saling menafikan di antara keduanya. Kedua ayat ini tidak saling menafikan, karena pada dasarnya kedua ayat ini مستقلة atas sebab zatnya dan tidak memerlukan hal lain selain daripadanya dalam menjelaskan maksud dalil-dalil itu. Selain itu, manfaat keperluan تعارض مل ialah untuk menyatukan hukum dan meminimalisir تعل المطلق على المقيد (pertikaian dalil) yang secara dasarnya berbeda. Apabila hukum keduanya berbeda secara nas seperti pada keadaan ini, maka hilanglah keperluan الحمل itu. Di antara jalan penyelesaian ialah lafaz الأيدي pada ayat pencurian telah ada taqyid-nya pada sunnah fíliyah dan qawliyah yaitu الرسغ sebagai batas potong tangan. Di antara hadis berkenaan ialah sebagai berikut:

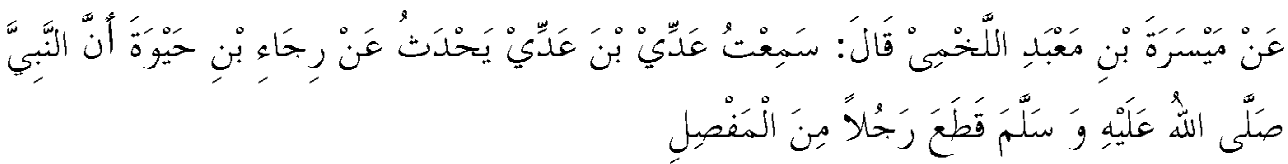


"Diriwayatkan dari Maisarah ibn Ma‘bad al-Lakhmiy ia berkata: Aku mendengar 'Addiy ibn 'Addiy menceritakan dari Rija' ibn Haiwah bahwa Nabi SAW telah memotong tangan (seorang pencuri) dari pergelangan tangannya" (Syaibah, 1989: 528).

Pelaksanaan hukuman ḥadd yang dilakukan oleh Nabi saw. dipandang sebagai تقييد atas مطلق ayat. Sunnah Nabi saw. ini diikuti oleh sahabat pada generasi berikutnya. Misalnya Umar ibn al-Khattab juga memotong tangan pencuri sampai ke pergelangan tangannya (Syaibah, 1989: 528). Apabila dijumpai dalil yang berfungsi sebagai sقيد, maka masalah ini keluar dari penggunaan kaidah حمل المطلق على المقيد, karena kaidah ini diperlukan ketika tidak ada dalil yang menjelaskan maksudnya.

\section{Hubungan tangan kiri (اليممال) dan tangan kanan (اليمين)}

Apabila حد السرقة dijadikan sebagai hukum dalam pencurian, maka disebutkan juga akibat dari perbuatan mencuri itu, karena hukum sesuatu mewujudkan akibat lain di sisinya. Pemotongan tangan kanan seorang pencuri sampai pada pergelangan berdasarkan surat alMāiidah ayat فاقطعو آيليهيما و السطارق والسارقة yang telah disebutkan di atas.

Dalam ayat ini terdapat lafaz أيديرما. Menurut ketentuan bahasa Arab sebagai bahasa al-Qur'an, segala aspek yang disandarkan pada penciptaan berpasangan (من الخنلث إلى اثنين), maka masing-masing dari keduanya dipandang satu dan apabila digabung kedua-duanya juga dipandang satu (Nujaim, 2002: 99). Pada hakikatnya sebagian besar dari anggota tubuh manusia itu berpasangan. Dengan demikian dipakaikan jumlah yang sedikit kepada jumlah yang banyak (حمل الأقل على الأكثر). Misalnya terdapat ungkapan عيو فما yaitu lafaz jamak (mata-mata) yang bermakna dua atau satu mata (إثنان) (Arabiy, 1967: 612 dan 613). Selain contoh itu Allah swt. berfirman dalam surat al-Tahrim ayat 4 sebagai berikut:

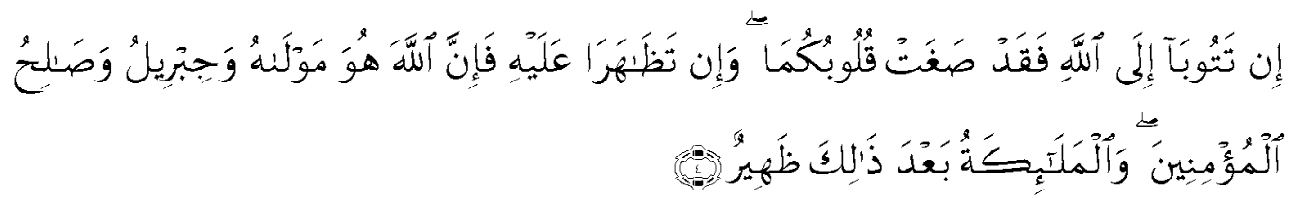

"Jika kamu berdua bertaubat kepada Allah, maka sesungguhnya hati kamu berdua telah condong (untuk menerima kebaikan); dan jika kamu berdua bantu membantu menyusahkan Nabi, maka sesungguhnya Allah adalah Pelindungnya dan (begitu pula) Jibril dan orangorang mu'min yang baik; dan selain dari itu malaikat-malaika penolongnya pula." 
ljtihad, Jurnal Wacana Hukum Islam dan Kemanusiaan, Volume 13, No. 1, Juni 2013: 85-104

Lafaz فقد صغت قلو بكما pada ayat ini ialah berpasangan (يثي), padahal makna sebenarnya ialah satu hati (gabungan dari dua belah hati) atau الجمe Demikian pula pengertian (dua) tangan pada lafaz أيديهم lyang tercantum pada surat al-Māंidah ayat 38 yaitu mengandung makna tangan kanan (اليمين) dan tangan kiri (الثشمال) sekaligus. Oleh karena itu tertera dalam al-Qur'an فاقطعو آليديهما dan tidak disebutkan oleh Allah dengan lafaz يلديهما ialah potonglah bagian kanan dari ini dan bagian kanan dari ini (فاقطعو اكمينا من هذا ويمينا من هذا). Sekalipun secara asal bisa diungkapkan dengan perkataan فاقطعو آأيديهما (al-Qurtubiy, 2002: 102). Ibn 'Arabiy menjelaskan bahwa perkataan مغرد yang dijamakkan menghendaki التثنية. Ungkapan ini tidak bermaksud hanya bagian kanan saja (اليمين) yang dipotong. Namun dipotong tangantangan (الأيدي) dan kaki-kaki (الأرجل). Dengan demikian lafaz ayat أليديهما kembali pada empat anggota badan yaitu gabungan dari dua tangan dan dua kaki ('Arabiy, 1967: 612-613).

Berdasarkan penjelasan itu, pengertian ini dijadikan hujah oleh beberapa ulama untuk membenarkan hukuman potong tangan kiri pada pencurian ketiga dan potong kaki kanan pada pencurian keempat. Al-Amidiy menyebutkan apabila Allah swt. mewajibkan hukuman potong tangan dan kaki, maka dibolehkan untuk memotong tangan dan kakinya yang lain pada pencurian-pencurian yang lain pula (al-Amidiy, t.th: 161). Akan tetapi hal ini diperdebatkan oleh ahli fiqh, karena berhubungan dengan akibat setelah pemotongan dua tangan dan dua kaki pada si pelaku serta ketiadaan naș sarị̣ yang menjelaskan kedudukannya.

Surat al-Māidah ayat 38 di atas hanya menjelaskan tentang pencurian yang dilakukan pertama kali. Tidak dijumpai ayat al-Qur'an lain yang menjelaskan mengenai hukuman pencurian pada kali kedua, ketiga, dan seterusnya. Dalam sebuah hadis dikemukakan sebagai berikut:

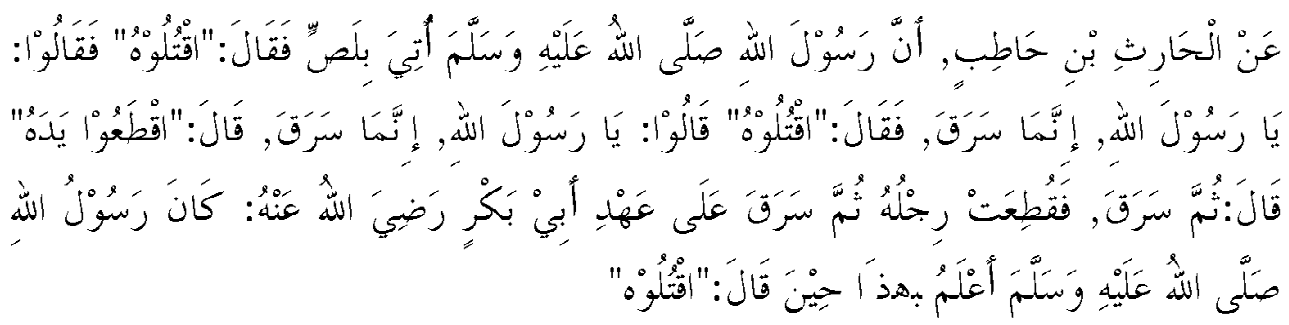


"Hadis diriwayatkan dari al-Haris ibn Hatib bahwa Rasulullah saw. didatangkan kepadanya seorang pencuri, maka Rasulullah saw. berkata:’Bunuhlah ia!” Orang-orang yang membawanya berkata: Wahai Rasulullah, ia hanya mencuri, Rasulullah saw. berkata:'Bunuhlah ia!' Mereka berkata lagi: Wahai Rasulullah, ia hanya mencuri, Rasulullah saw. berkata:'Potonglah tangannya!' Kemudian ia mencuri lagi, maka dipotong kakinya, kemudian ia mencuri lagi pada masa pemerintahan Abu Bakar. Abu Bakar berkata: Rasulullah saw. lebih mengetahui masalah ini ketika Beliau bersabda:'Bunuhlah ia!” (alNasaiy, 1999: 423-424).

Hadis ini menjelaskan bahwa pencuri yang mencuri pertama kali dihukum dengan hukuman potong tangan kanan. Apabila ia mencuri untuk kedua kalinya, maka dipotong kaki kanannya. Adapun hadis berikutnya menjelaskan tentang pemotongan tangan kiri pada pencurian ketiga dan pemotongan kaki kanan pada pencurian keempat seperti berikut ini:

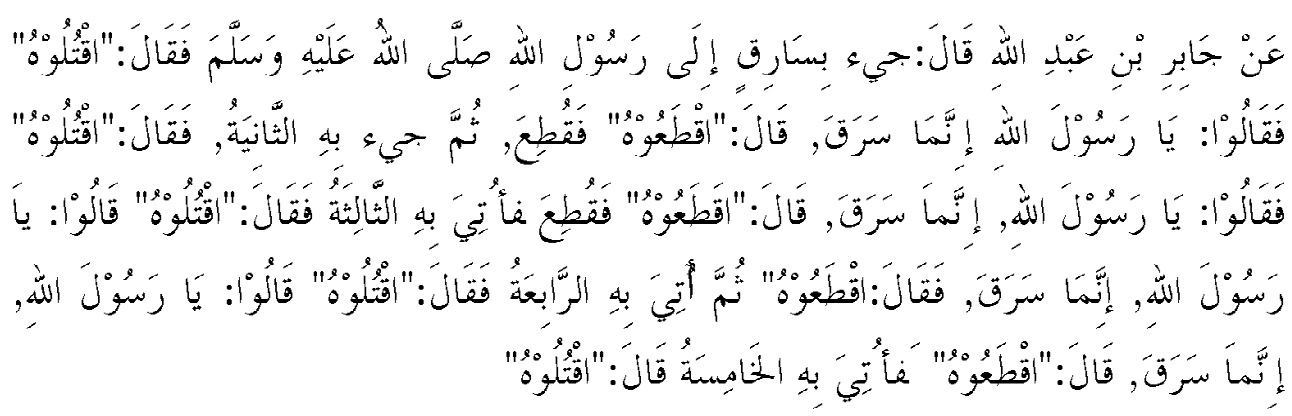

"Hadis diriwayatkan dari Jabir ibn 'Abdillah dia berkata: Didatangkan seorang pencuri kepada Rasulullah saw., maka Beliau berkata:’Bunuhlah ia!” Orang-orang yang membawanya berkata: Wahai Rasulullah, ia hanya mencuri, maka Rasulullah saw. berkata:'Potonglah!' Kemudian si pencuri didatangkan kedua kalinya, Rasulullah saw. berkata:'Bunuhlah ia!' Mereka berkata: Wahai Rasulullah, ia hanya mencuri, Rasulullah saw. berkata:'Potonglah!"' Kemudian si pencuri didatangkan ketiga kalinya, Rasulullah saw. berkata:'Bunuhlah ia!' Mereka berkata: Wahai Rasulullah, ia hanya mencuri, Rasulullah saw. berkata:'Potonglah!” Kemudian si pencuri didatangkan keempat kalinya, Rasulullah saw. bersabda:'Bunuhlah ia!' Mereka berkata: Wahai Rasulullah, ia hanya mencuri, Rasulullah saw. berkata:'Potonglah!" Kemudian si pencuri didatangkan untuk kelima kalinya, Rasulullah saw. berkata:’Bunuhlah ia!” (al-Nasaiy, 1999: 424-425).

Hadis ini menjelaskan bahwa pencurian yang dilakukan berulang kali dapat dikenakan empat kali hukuman potong. Hadis ini tidak menjelaskan bagian-bagian tubuh mana saja yang mesti dipotong. Namun berdasarkan bacaan Ibn Mas'ud, maka bagian tubuh pertama 
ljtihad, Jurnal Wacana Hukum Islam dan Kemanusiaan, Volume 13, No. 1, Juni 2013: 85-104

yang dipotong ialah tangan kanan, pada pencurian kedua dipotong kaki kiri, pada pencurian ketiga dipotong tangan kiri, dan pada pencurian keempat dipotong kaki kanan. Berdasarkan hadis ini seorang pencuri akan kehilangan dua tangan dan dua kakinya setelah mencuri keempat kalinya. Walaupun demikian, hadis ini diperdebatkan oleh para ahli ilmu. Salah seorang sanadnya yang bernama Mus'ab ibn Sabit dianggap tidak kuat dalam periwayatan hadis. Namun menurut al-Albaniy hadis ini tidak bersendirian karena terdapat periwayatan lain yang diterima dari Hisyam ibn 'Urwah yang mempunyai tiga periwayatan mengenai hadis ini (al-Nasaiy, 1999: 424-425).

Di kalangan sahabatpun terdapat perbedaan pendapat tentang tangan kiri dan kaki kanan ini. Berdasarkan hadis yang diriwayatkan dari Mus'ab ibn Sabit di atas, tidak dapat dipastikan keputusan Abu Bakar terhadap si pencuri yang telah mencuri sebanyak tiga kali. Ada yang mengatakan bahwa Abu Bakar tidak memotong kaki kanannya, tetapi memasukkannya ke dalam penjara (Qal'ajiy, 1983: 142- 143). Ada pula yang mengatakan bahwa setelah mendapatkan pertimbangan dari Umar, Abu Bakar memotong tangan kiri si pencuri (alKandahlawiy, 2003: 436- 437).

Umar ibn al-Khattab sangat tegas dalam masalah ini. Beliau memotong tangan kiri pencuri pada pencurian ketiga kalinya dan memotong kaki kanan si pencuri pada pencurian keempat (Qal'ajiy, 1986: 495- 496). Umar memerintahkan umat Islam untuk dapat melaksanakan hadd pencurian berdasarkan surat al-Māéidah ayat 38 (فاقطعو آأيديهما). Beliau mengatakan bahwa tidak dibenarkan untuk mengganti tangan (kiri) dengan kaki kanan atas dasar mempertimbangkan tangan si pencuri yang akan digunakannya untuk makan, bersuci dan lain-lain, karena hal ini menyalahi Sunnah Rasulullah saw. seperti yang diriwayatkan oleh Mus'ab ibn Sabit di atas (Fauriy, 1954: 311).

Ali ibn Abi Talib tidak memotong tangan kiri dan kaki kanan pencuri pada pencurian ketiga dan keempat. Buktinya beliau dinukilkan berkata:

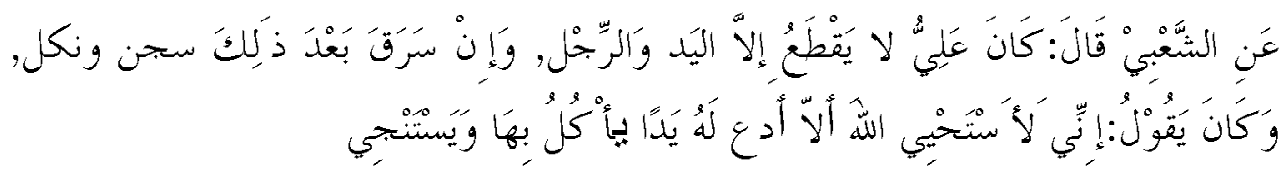


"Khabar diriwayatkan dari al-Sha'biy ia berkata: Ali tidak memotong pencuri kecuali satu tangan dan satu kaki. Apabila dia kembali mencuri maka Ali memenjarakan dan membalasinya/mendidiknya. Ali berkata:"Sesungguhnya aku malu kepada Allah bahawa aku mengambil tangan yang digunakannya untuk makan dan istinjak" (al-San'aniy, 2000: 482).

Ali berpendapat bahwa memotong kedua tangan akan menghilangkan seluruh fungsi tangan, sehingga tidak ada lagi alat bagi si pencuri untuk makan, berwudhu, dan aktivitas tangan lainnya. Ini bermakna hukuman ḥadd pencurian mengakibatkan kebinasaan lebih dari yang sepatutnya. Apabila dipotong pula kaki kanannya pada pencurian seterusnya, maka akan semakin menambah kebinasaan yang telah ada pada pemotongan tangan kanan dan kaki kirinya itu (Qudamah, t.th: 265).

Ulama mazhab Hanafi mengatakan bahwa orang yang mencuri pertama kali dipotong tangan kanannya. Apabila ia kembali mencuri kedua kalinya, maka dipotong kaki kirinya. Apabila ia mencuri ketiga kalinya, maka tidak dihukum dengan hukuman potong tangan kiri, tetapi si pencuri dipenjarakan (al-Jassas, t.th: 422). Dalil yang mereka kemukakan di antaranya bahwa Allah swt. berfirman فاقطعب آليديهما dalam surat al-Māiidah ayat 38. Maksud dari lafaz أيديهما ialah tangan kanan (أليمين) seperti tertera dalam bacaan Ibn Mas'ud dan bacaan yang sama juga didengar dari Ibn 'Abbas, al-Hasan dan Ibrahim. Dengan demikian maksud dari dalam ayat ini ialah satu tangan (kanan) saja. Artinya tidak dibenarkan untuk menambahnya dengan tangan yang lain (kiri) kecuali terdapat petunjuk lain yang lebih sarị̆. Selain itu, telah ada kesepahaman mengenai hukuman potong kaki kiri pada pencurian untuk kedua kalinya, tetapi diperdebatkan mengenai pencurian ketiga dan keempat. Atas dasar itu tidak dibenarkan untuk memotong tangan kiri seorang pencuri dengan tidak ada kesepahaman dan petunjuk jelas dari Nabi saw. Pada keadaan ini tidak dibenarkan menetapkan hukuman ḥudūd dengan tidak ada kesepahaman dan petunjuk yang sarīh.

Selain itu, telah ada kesamaan pendapat untuk memotong kaki kanan pada pencurian kedua kalinya. Hal ini menjadi dalil bahwa sepatutnya tangan kiri tidak dipotong lagi. 'Illah pemotongan kaki kanan setelah tangan kiri ialah untuk mempertahankan fungsi ke(dua) 
ljtihad, Jurnal Wacana Hukum Islam dan Kemanusiaan, Volume 13, No. 1, Juni 2013: 85-104

tangan. Demikian pula sebaliknya, 'illah tidak dipotongnya kaki kiri pada pencurian yang keempat ialah untuk mempertahankan fungsi kedua kaki, di antaranya untuk berjalan.

Juga dikemukakan bahwa terdapat kesepahaman untuk memotong tangan kanan dan kaki kiri perampok/pelaku hirābah (المحارب) dan disepakati pula untuk tidak menambah pemotongan lebih dari dua anggota berkenaan. Jināaha hirāabab ialah jināalah yang lebih besar kemudaratannya dan lebih berat hukumannya dari jinajah pencurian. Oleh sebab itu tidak sepatutnya hukuman pencurian lebih berat dibanding hukuman hirāabah (al-Sarakhsyiy, 1324 H: 140-141).

Adapun ulama-ulama lain seperti ulama mazhab Syafíi berpendapat bahwa pencurian kedua dipotong tangan kiri dan pada pencurian keempat dipotong kaki kanan (al-Damiriy, 2004: 193-194). Argumentasi yang mereka gunakan di antaranya hadis yang diriwayatkan oleh Mus'ab ibn Sabit yang telah dikemukakan di atas mengenai perintah Nabi saw. untuk memotong tangan dan kaki yang tersisa pada pencurian ketiga dan keempat.

Juga dikatakan bahwa tangan dan kaki ialah alat yang digunakan untuk mencuri yaitu mengambil harta curian dan memindahkannya ke tempat lain. Sekalipun si pencuri telah dipotong tangan kanan dan kaki kirinya, tetapi ia masih memiliki tangan kiri dan kaki kanan yang membuatnya masih bisa untuk mencuri kembali.

Utamanya lagi potong tangan kiri pada pencurian ketiga dan potong kaki kanan pada pencurian keempat di-qiyas-kan kepada jināyah hiriābah, karena pencurian ketiga dan seterusnya itu setara kedudukannya dengan jināyah hirāabah ini. Di antara hukumannya ialah potong tangan dan kaki secara bersilang seperti dijelaskan dalam surat al-Māiidah ayat 33 (أو تقطع أيديهم وأربلهم من خلاف).

Ulama mazhab Maliki dan ulama mazhab Hanbali juga mempunyai pendapat yang sama. Selain argumentasi yang telah dikemukakan di atas, mereka mengatakan bahwa satu pencurian mempunyai satu hadd. Dengan demikian, untuk memelihara hukum-hukum Allah, setiap kali pencurian mesti dilaksanakan hukuman potong tangan atau kaki (al-Haitamiy, 1997: 181-182).

Ibn 'Atiyyah mengatakan bahwa sebab dijamakkannya perkatan الأيدي dalam lafaz ayat فاقطعو آيديهما ialah karena masing-masing dari pencuri yaitu lelaki yang mencuri 
mempunyai satu tangan kanan (اليمين) yang akan dipotong dan perempuan yang mencuri mempunyai satu tangan kanan yang akan dipotong. Seolah-olah dikatakan potonglah tangan kanan dari kedua jenis lelaki dan perempuan ini. Adapun التثنية berfungsi sebagai ad-damir bagi dua jenis lelaki dan perempuan. Zahir firman Allah أليديهما (للضمير) ialah tidak dipotong kaki dalam pencurian. Apabila seseorang mencuri untuk pertama kalinya, dipotong tangan kanannya. Apabila ia mencuri pada kali kedua, dipotong tangan kirinya. Apabila ia mencuri pada kali ketiga, maka ia dihukum dengan hukuman penjara (Hayyan, t.th: 483). Hal ini dipahami karena tidak ada lagi tangan yang akan dipotong sementara ayat menghendaki tangan yang wajib dipotong dan bukan kaki si pencuri.

\section{Tangan kanan (اليمين) mengikuti bacaan Ibn Mas'ud}

Selain penjelasan yang telah dikemukakan di atas, lafaz أيديهما yang disandarkan pada tangan kanan (اليمين) berdasarkan pada bacaan Ibn Mas'ud yaitu أيماكمان seperti yang disebutkan dalam hadis berikut ini:

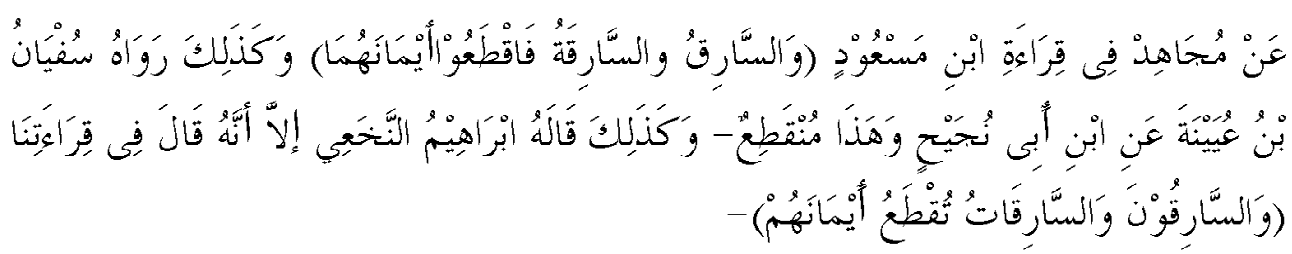

"Khabar diterima dari Mujahid mengenai bacaan Ibn Mas'ud yaitu orang lelaki yang mencuri dan orang perempuan yang mencuri maka (hukumnya) potonglah tangan kanan mereka. Hal demikian juga diriwayatkan oleh Sufyan Ibn 'Uyaynah dari Ibn Abi Nujaih (munqati'). Demikian pula dikatakan oleh Ibrahim al-Nakha'iy yang mengatakan bahwa bacaan kami ialah orang-orang lelaki yang mencuri dan orang-orang perempuan yang mencuri maka (hukumnya) potonglah tangan kanan mereka" (al-Baihaqqiy, 1994: 270).

Khabar ini menjelaskan bahwa bacaan (قر أقة) Ibn Mas'ud ketika mendengar Nabi saw.

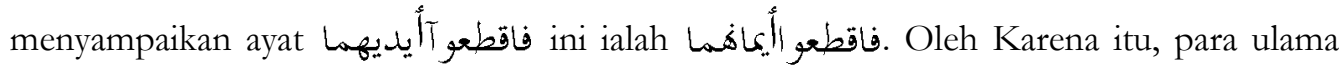
sependapat untuk memakaikannya pada ayat tersebut dan melaksanakan pemotongan tangan kanan pada pencurian pertama. Khabar ini ialah khabar yang masyhur (خبر مشهور) yang berhubungan dengan kemutlakan naṣs dan tidak merupakan bentuk penakwilan. Dengan 
ljtihad, Jurnal Wacana Hukum Islam dan Kemanusiaan, Volume 13, No. 1, Juni 2013: 85-104

demikian, pada hakikatnya tidak terdapat sifat mujmal pada ayat ini, sehingga Rasulullah saw. telah memotong tangan kanan seorang pencuri sampai pada pergelangannya (الز ند) yaitu

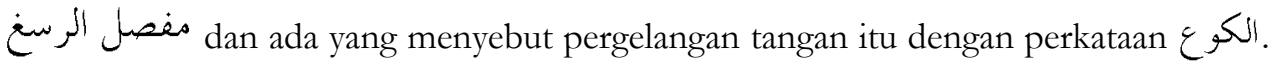

\section{Penutup}

Pemahaman hukuman pencurian yang telah biasa didengar dan dipahami masyarakat ialah potong tangan seperti yang dijelaskan dalam al-Qur'an. Akan tetapi masih terdapat perbedaan pendapat tentang hukuman potong yang sebenarnya dari sudut pandang usul fikih. Perbedaan ini dilatarbelakangi oleh lafaz qat ${ }^{6}$ dan yad yang mempunyai makna lebih dari satu. Perbedaan ini juga dengan sendirinya memberi pengaruh pada pengertian qat $t^{6}$ al-yad yang dimaksud dalam al-Qur'an surat al-Māicidah ayat 38.

Tujuan syarak dalam pelaksanaan hukuman potong tangan ialah untuk memelihara kemaslahatan harta. Allah swt. menetapkan bahwa hukuman bagi orang yang mencuri ialah dipotong tangannya. Terlepas dari perbedaan pendapat mengenai batas tangan dan makna dipotong, mayoritas ulama berpendapat bahwa hukuman potong tangan itu ialah diputus sehingga terpisah dari bahagian tangan/tubuh. Pendapat mayoritas ini dibantah oleh sebahagian kecil ulama kontemporer dengan mengatakan bahwa hukuman bagi orang yang mencuri ialah tidak mesti hukuman potong tangan, karena dijumpai dalam hadis Rasulullah

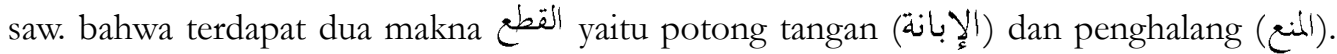
Selain itu, memecah dan melukai biasanya juga diungkapkan dengan kata القطع. Atas dasar itu, hukuman potong tangan dalam hukum Islam ini lebih fleksibel dari apa yang selama ini dipahami oleh masyarakat. Luasnya pengertian tangan yang dipahami ulama serta dalil-dalil yang mereka gunakan dapat memberikan peluang penerapan yang lebih besar dalam dunia Islam, khususnya dalam aturan hukum Indonesia sebagai negara dengan penduduk muslim terbanyak di dunia.

\section{Daftar pustaka}

Al-Qur'an al-Karim.

Al-Amidiy. al-Iḥkāam fì Ușul al-Aḥkàm. Jil. 3\&4. Kairo: Muassasah al-Halabi, t.th.

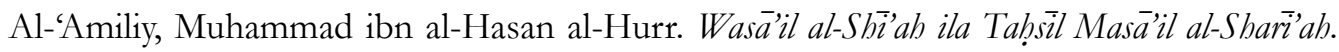
Jil. 18. Beirut: Dār al-Iḥyā' al-Turāth, 1991. 
'Arabi, Ibn. Aḥkēm al-Qur'àn. Jil. 2. Mesir: 'Isa al-Bāb al-Halibī, 1967.

Al-Baihaqqiy. al-Sunan al-Kubrā. Jil. 8. Beirut: Dār al-Kutub al-'Ilmiyah, 1994.

Al-Damiriy, Kamal al-Din Abiy al-Baqa' Muhammad Ibn Musa Ibn 'Isa. al-Najm al-Wahhāb fi Sharḥ al-Minhäj. Jil. 9. Beirut: Dār al-Minhāj, 2004.

Fauriy, Al-Muttaqa al-Hindiy al-Burhan. Kanz al-'Ummäl fi Sunan al-Aqwäl wa al-Af'al. Jil. 5. al-Hindiy: Maṭa'ah Majlis Dả'irah al-Ma'árif, 1954.

al-Haitamiy, Syihab al-Din Ahmad Ibn Hajr. Hawashi al-Shaykh al-Hamid al-Sharwañi wa al-Shaykh Aḅmad Ibn Qāsim al-Tbääi. Juz. 9. Beirut: Dār al-Fikr, 1997.

Hazm, Ibn. al-Muhalla, Juz. 11. Beirut: al-Maktab al-Tijari, t.th.

Hayyan. Ibn, Tafsir al-Baḥr al-Muḥit. Jil. 3. Riyad: Maktabah al-Nasr al-Hadithah, t.th.

Al-Jassas. Tafsir Āyat al-Ạ̣kéam. Jil. 2. Beirut: Dār al-Kitāb al-'Arabīi, t.th

Al-Kandahlawiy, Muhammad Zakariyya. Awjāz al-Masālik ila Muwaț̣a' Mālik. Juz. 15. Damsyq: Dār al-Qisā', 2003.

Al-Mu'taziliy, Abi al-Husain Muhammad Ibn 'Ali Ibn al-Tayyib al-Basriy. al-Mưtamad $\bar{f}$ Usū al-Figh. Juz. 1. Damshq: al-Ma had al-'Ilmi, 1964.

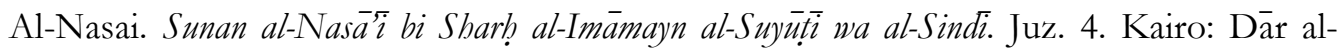
Hadith, 1999.

Nujaim, Ibn. al-Bạ̣r al-Räiq Sharḥ Kanz al-Daqā'iq. Juz. 5. Beirut: Dār Ihyāà al-Turāth al'Arabi, 2002.

Qal'ajiy, Muhammad Rawwas. Mawsū ah Fiqh Abi Bakr al-Siddiqq. Beirut: Dār al-Nafá'is, 1983.

Qal'ajiy, Muhammad Rawwas. Mawsū ah Fiqh'Ali Ibn Abi Ṭälib. Beirut: Dār al-Nafá'is, 1996.

Qal'ajiy, Muhammad Rawwas. Mawsū ah Fiqh Umar Ibn al-Khatțāb. Beirut: Dār al-Nafā'is, 1986.

Qudamah, Ibnu. al-Mughn̄i. Beirut: Dār al-Fikr, t.th.

Al-Qurtubiy. al-Jami‘ al-Aḥkēm al-Qur'ān. Jil. 3. Beirut: Dār al-Iḥyā' al-Turāth al-'Arabi, 2002.

al-Samarqandiy, al-Darimiy. Sunan al-Darimiy. Jil. 1. Kairo: Dar al-Hadis, 2000.

Al-San'aniy, Abu Bakr 'Abd al-Razzaq ibn Hammam ibn Nafi'. al-Musannif. Jil. 9. Beirut: Dār al-Kutub al-'Ilmiyah, 2000.

Al-San'aniy, Muhammad Ibn Isma'il al-Yamaniy. Subūl al-Saläm Sharḅ Bulügh al-Marām min Jämi’ Adillat al-Aḥkām. Jil. 1. Kairo: Dār al-Hadith, 1997.

Salih, Muhammad Adib. Tafsìr al-Nușiss $\bar{f}$ al-Figh al-Islamī. Jil. 2. Beirut: al-Maktab al-Islami, 1993. 
ljtihad, Jurnal Wacana Hukum Islam dan Kemanusiaan, Volume 13, No. 1, Juni 2013: 85-104

Syaibah, Ibn Abi. al-Musannif fi al-Aḥadith wa al-Athar. Jil. 6. Beirut: Dār al-Fikr, 1989. Al-Sarakhsyiy. Kitāb al-Mabșüt. Jil. 9\&10. Mesir: Matba'ah al-Sa'ádah, 1324H. Al-Syaukaniy. Irshäd al-Fubūl. Kairo: Dār al-Kutub, t.th.

Subkiy, Ibnu. Jam` al-Jawāmi'. Jil. 2. Kairo: Dār al-Ihyā̄' al-Kutub al-‘Arabiyah, 